\title{
DISCORD AND SOLIDARITY AMONG THE ARABS IN THE NETHERLANDS EAST INDIES, 1900-1942
}

\author{
Huub de Jonge
}

Arabs are the second most important minority of foreign origin in present-day Indonesia. Like the more numerous Chinese, they play an important role in the economic life of the country, as entrepreneurs, traders, shopkeepers, or money-lenders and, like the Chinese, they, too, are a clearly differentiable ethnic group. Prejudices that exist toward the Arabs correspond, to a certain degree, with those toward the Chinese. Both groups, for instance, are accused of engaging in dishonest competition, usurious practices, forming protective trade associations, bribery, and giving preference to members of their own group. Yet open hostility is seldom if ever displayed toward Arabs. The reason for this lack of animosity can be found in the smallness of the Arab community and in their national and religious identity. Numbering no more than a fraction of the Chinese population in Indonesia, ${ }^{1}$ Arabs today feel themselves to be Indonesians, in spite of all the social and cultural differences. In contrast to the Chinese, nearly all Arabs became Indonesian citizens when Indonesia gained its independence, and are generally accepted in their social environment as fellow countrymen or compatriots. This acceptance stems in part from the Arabs' religion, Islam, which is the same as that of the larger part of the Indonesian population. ${ }^{2}$ In religious matters Arabs generally enjoy much esteem. They come from the Arabian peninsula, the cradle of Islam, and had an important part in the spread and refinement of Islam in Indonesia. Their religious status neutralizes to some extent their economically unequal position. Their acceptance is also apparent from the many positions they hold in political and administrative areas. In 1992 there were three cabinet members of Arab origin and not a single one of Chinese descent.

This article is based on archival and library research as well as on data collected during various stays in Indonesia. I am very grateful to Henk Driessen and Robert Wessing for their comments on the first draft of this article.

${ }^{1}$ In recent years, Arab leaders on Java with whom I spoke estimate that there are about 150,000 persons of Arab descent in Indonesia.

2 See Charles Coppel, "Arab and Chinese Minority Groups in Java," Southeast Asia Ethnicity and Development Newsletter 3, 2 (1979): 8-15. 
The basis for Arab identification with Indonesia was laid in the early decades of this century, or more precisely between 1912 and 1934. In that period extensive disputes and dissension occurred among the Arabs of the archipelago. Under the influence of nationalist emancipation movements at home and abroad, a kind of social revolution took place within their relatively closed community. Arabs of lower rank no longer accepted the position of the traditional upper stratum and succeeded in overthrowing the strong hierarchical societal order which orginated in Southern Arabia. The tensions within the community not only led to new social identities, but also facilitated the transition from a primarily Arab to a primarily Indonesian identity.

In this article I want to expound the shifts in social identity and concomitant changes in national identity among the Arabs in Indonesia. I will do that by analyzing a conflict that arose at the end of the 1920s over the use of the title sayid, a title traditionally borne by members of the upper stratum, a kind of "spiritual aristocracy." At that time, Arabs of the lower strata no longer tolerated the traditional elite's exclusive right to use this title, denying that it denoted a special status. They, therefore, started to use the title themselves. The fight over the use of the term sayid to a high degree symbolizes the social tensions in the Arab community between those struggling for emancipation and those vigorously trying to maintain the existing social order. For a better understanding of the internal discord, I will first detail the historical background and the social characteristics of the Arab population in Indonesia.

\section{The Arab Minority in the Netherlands East Indies}

The first indications of Arabs visiting maritime Southeast Asia date from the tenth century. In the following centuries their number must have gradually increased. In any event, Arabs traded and contributed directly to the spread of Islam, ${ }^{3}$ and in the fifteenth century small Arab communities could be found in most of the important coastal places of the Indonesian archipelago. 4 Some Arabs succeeded in acquiring a great deal of influence in these areas, and various Islamic trading states, that arose on the north coast of Java in the sixteenth century, were ruled by persons of Arab origin. ${ }^{5}$ At the end of the eighteenth century Arab fortune hunters founded their own states in Sumatra and Kalimantan. 6

Many of these immigrants probably blended into the local population or migrated elsewhere. At the beginning of the nineteenth century, no more than 621 Arabs and Moors lived on Java, as traders and religious leaders. ${ }^{7}$ Throughout the century the number of Arabs again rose, especially after the opening of the Suez Canal in 1869. Each year thousands of Arabs migrated eastwards. Between 1870 and 1900 the Arab minority in the Netherlands East Indies increased from about 13,000 to $27,000 .^{8}$ In 1920 the Arab community listed 45,000

${ }^{3}$ Cf. M. C. Ricklefs, "Six Centuries of Islamization," in Conversion to Islam, ed. Nehemia Levtzion (New York: Holmes \& Meier, 1979), pp. 104-5.

4 J. M. van der Kroef, Indonesia in the Modern World, vol. 1 (Bandung: Masa Baru, 1954), p. 252; J. C. van Leur, Essays in Asian Social and Economic History (The Hague: Van Hoeve, 1967), p. 139.

${ }^{5}$ For details see H. J. de Graaf and Th. G. Pigeaud, De eerste moslimse vorstendommen op Java. Studiën over de staatkundige geschiedenis van de 15de en 16de eeuw, Verhandelingen van het Koninklijk Instituut voor Taal-, Landen Volkenkunde, no. 69 (The Hague: Nijhoff, 1974).

6 Van der Kroef, Indonesia 1: 253.

7 T. S. Raffles, The History of Java, vol.1 (London: Black, Parburry \& Allen, 1817), pp. 63, 75.

${ }^{8}$ Van der Kroef, Indonesia 1: 250. 
members, and by 1930 their number had risen to $71,335 .{ }^{9}$ Although reliable figures are not available for later years, continuous immigration must have resulted in there being close to 80,000 Arabs in the colony on the eve of the Japanese occupation. ${ }^{10}$

The great majority of the Arabs originated in Hadramaut, a region in South Yemen, which in 1990 merged with North Yemen to become the Republic of Yemen. The others came primarily from the Hejaz, the region in which Mecca and Medina are located. While the Hadramis came to trade, Arabs from the Hejaz traveled back and forth to the Indonesian archipelago in order to recruit and accompany hajjis. In the beginning, most of the immigrants, who were almost all men, were not planning to settle in the archipelago. They wanted to earn money quickly in order to aid their poor relatives, or to save money in order to assure themselves a better future. Great sums of money were sent home each year. ${ }^{11} \mathrm{Al}-$ though many migrants returned home, most remained in the archipelago. A large part of these young immigrants married in their new environment, inhibiting their return. At the beginning of the nineteenth century most of them married local women; but later they married primarily descendants of these mixed marriages, muwalad or peranakan Arabs. ${ }^{12}$ Many immigrants preferred an assured existence in the Indies to an uncertain future in Hadramaut. The good sea connections with Southern Arabia prior to the Second World War made it always possible to return to their land of origin for a longer or shorter period. Some even had a second home or a second wife there. At that time, it was not unusual for children to be sent to Hadramaut for a number of years to obtain a good education. ${ }^{13}$

The Hadramaut is an infertile, mountainous region. Until far into the present century it was remote. At the beginning of the century a journey by foot from the most important port cities of Makalla and al-Syihr to the relatively densely populated wadi in the hinterland took five to eight days. ${ }^{14}$ Tribal wars, family feuds, banditry, and robbery long made the region unsafe. The majority of the population survived from irrigated agriculture, possible only in the riverbeds when enough rain fell. In order to stay alive a considerable portion of the male population was forced to seek work elsewhere. During the nineteenth century they went to India, East Africa, and the countries around the Red Sea, but after the turn of the century, the Netherlands East Indies and the British Straits Settlements became the most important destinations. In 1934 about a quarter of the Hadramis lived outside the Hadramaut, with their largest colony located in the Netherlands East Indies. ${ }^{15}$

\footnotetext{
9 Ibid.; For details see Volkstelling 1930, Part VII, "Chineezen en andere Vreemde Oosterlingen in NederlandschIndië," (Batavia: Landsdrukkerij, 1935).

${ }^{10}$ According to Van der Kroef (Indonesia 1: 250, 273) Indonesia had 85,000 Arab inhabitants in 1952. He got this estimate from the Interior Ministry of the Indonesian Republic. The figure, probably "inherited" from the colonial administration, is far from reliable. Due to World War II and the struggle for independence, the registration cannot have been complete.

11 A. S. Bujra, "Political Conflict and Stratification in Hadramauth-I," Middle Eastern Studies 3, 4 (1967): 355-75.

12 Muwalad is the Arab, peranakan the Indonesian term for persons of mixed descent.

13 See D. van der Meulen and H. von Wissmann, Hadramaut: Some of its Mysteries Unveiled (Leiden: Brill, 1932), pp. 33, 89, 96; D. van der Meulen, Onbekend Arabië (Amsterdam: Meulenhoff, 1951), p. 145.

14 Cf. L.W.C. van den Berg, Le Hadramaut et les colonies arabes dans l'archipel indien (Batavia: Imprimerie du Gouvernement, 1886), pp. 17-32; Van der Meulen and von Wissmann, Hadramaut, passim.

15 Bujra, "Political Conflict," p. 367. For more about the Hadrami who migrated to the Indian coast see J. Kostiner, "The Impact of the Hadrami Emigrants in the East Indies on Islamic Modernism and Social Change in the Hadramat during the 20th Century," in Islam in Asia, 2 vols., ed. R. Israeli and A. H. Johns (Boulder: Westview Press, 1984), 2: 202-37.
} 
The importance of the Netherlands East Indies to the Hadramis in that period is evident from the reports of the first Europeans who traveled through the heart of the Hadramaut. 16 Everywhere they met inhabitants who had lived for some time on Java and spoke Malay, or who had family there. Many people regularly received money from Java. In this generally impoverished region, there were people living in stately homes or palaces, paid for with the earnings of migration labor. Some households had a Javanese or Chinese housekeeper or cook. 17

Until the founding of the state of South Yemen in 1967, Hadramaut was not united politically. For centuries it had been the scene of rival kingdoms, autonomous cities, and tribes. Although the Ottoman sultans counted Hadramaut as part of the caliphate, they never exercised any real authority there. According to Snouck Hurgronje (the famous Dutch Islam scholar who also advised the Dutch colonial governement on Arab affairs), a Turkish governor would only be able to maintain himself in this hotbed of factionalism through continual displays of power, ${ }^{18}$ and there were incessant rebellions against Turkish rule. In the nineteenth century British influence increased in South Arabia. They occupied Aden in 1839 , and during the last quarter of the century made treaties with kings and tribal leaders. After a diplomatic treaty with Turkey in 1904, the British gained possession of the area now called South Yemen. Initially they paid little attention to the hinterland. Only in the 1930s, when tribal wars and bloody feuds threatened to render the situation untenable, was a start made with the pacification of the Hadramaut. ${ }^{19}$ The most important vassals of the British in this endeavor were the heads of the al-Qua'ity and al-Kathiri families who each had a large sphere of influence in the Hadramaut and who ironically had until then fought each other. ${ }^{20}$

Hadrami society is marked by a fairly rigid, descent-based class structure. ${ }^{21}$ The highest class are the sayid who claim to be descended from the prophet Muhammad via his grandson Husein. ${ }^{22}$ They are also called Ba-'Alawi or Alawi after Alawi, a grandson of their clan ancestor Ahmad bin 'Isa ("the Emigrant"), who more than a thousand years ago moved to Hadramaut from Basra in Iraq. The sayid are the religious nobility of the Hadramaut. They occupy a privileged position, are always unarmed, and fulfill important religious and social tasks such as supervising the observance of religious duties, leading religious activities and ceremonies, and caring for Islamic education. Before the founding of the People's Republic of South Yemen, they acted as mediators and peacemakers between the warring parties and provided safe conduct through enemy territory. The people kiss the hand of sayid in greeting and make pilgrimages to the graves of holy sayid. Owing to the centuries-long isolation in the Hadramaut, the sayid see themselves as a purer noble lineage than the descendants of

${ }^{16} \mathrm{Cf}$. H. Ingrams, Arabia and the Isles (London: John Murray, 1942); F. Stark, A Winter in Arabia (London: John Murray, 1941); Van der Meulen and von Wissmann, Hadramaut; Van der Meulen, Onbekend Arabië.

17 Van der Meulen and von Wissmann, Hadramaut, pp. 96, 121.

18 E. Gobée and C. Adriaanse, Ambtelijke adviezen van C. Snouck Hurgronje, 1889-1936, 3 vols. (The Hague: Nijhoff, 1957-1959), 2: 1731.

19 See F. Moss, "Zuid-Jemen: aan de rand van het Arabisch schiereiland," in Bedoeienen en oliemagnaten aan de Golf, ed. H. Hernalsteen and U. Vermeulen (Leuven: Peters, 1988), pp. 79-91.

20 Gobée and Adriaanse, Ambtelijke adviezen, 2: 1529.

21 Cf. Van den Berg, Colonies arabes, pp. 32-48; A. S. Bujra, The Politics of Stratification. A Study of Political Change in a South Arabian Town (Oxford: Oxford University Press, 1971), pp. 13-53.

22 Sayid, in the Hadrami dialect of Arabic seyyid, is really the singular form of sadah. In Indonesian, however, there is no difference in spelling between the singular and the plural. The inhabitants of Arab descent have taken over this custom. In this article I always follow the Indonesian spelling. 
the Prophet in other countries. ${ }^{23}$ Besides fulfilling spiritual, educational, and political functions, the sayid also engage in economic activities. They own land and trade.

Below the sayid are two groups who form the middle layer of the society: the syekh and the gabili. ${ }^{24}$ Both groups claim to be descended from Qahtan, the ancestor of all southern Arabs. The syekh enjoy the higher status. They are an indigenous religious elite, descendants of theologians and wise men who fulfill the same tasks as the sayid. Fewer in number than the sayid, however, the group is eclipsed by the descendants of the Prophet. Just like the sayid, the syekh can devote themselves either partially or completely to worldly affairs. Members of the tribes are known as gabili. Each tribe has its own territory which, at least until the pacification of the Hadramaut, was defended with might and main. Members of the tribes formed their armed forces. In spite of their lower status, the gabili were in fact the real rulers of the Hadramaut. The al-Kathiri and the al-Qua'ity belong to this group.

At the bottom of the social scale are the masakin (lit. the poor) or da'fa (lit. weak)-those who are of unimportant origin. The group consists of traders, tradesmen, laborers and servants, and previously also slaves.

Until the 1970s, as far as is known, the boundaries between these three classes were strictly maintained in the Hadramaut and are expressed among other things in the marriage regulations. ${ }^{25}$ All three classes emphasize the principle of kafa'ah (equality of rank) between marriage partners, ${ }^{26}$ meaning that women never marry "beneath their social status." The sayid go so far as to disapprove of their daughters marrying with syarif, descendants of Hasan, another grandson of the Prophet. ${ }^{27}$ Men, however, may marry women of a lower status because descent is reckoned along the male line.

Bujra suspects that the majority of the migrants to Southeast Asia were sayid. ${ }^{28}$ Most were able to raise the money for the journey and to bring along a small amount of capital for trade. Batavia in the 1930s counted 700 members of the well-known al-Attas family-sayid from the town of Huraidah. ${ }^{29}$ Thousands from the other layers of society, however, must also have migrated eastwards. The masakin were undoubtedly the second largest group. They generally had no choice about migrating, for the continual poverty in which they found themselves in Hadramaut drove them away. Some left on their own with borrowed money or with an advance from an Arab sponsor in the Indies; others came in the service of a sayid or a syekh. Syekh and gabili migrated in fewer numbers, although they were present in almost every important Arab community on Java.

In the Netherlands East Indies, the Arabs were officially counted as Foreign Orientals, just like the Chinese and other foreigners from Asia (with the exception of the Japanese). As a result, they had different rights and duties from other categories of inhabitants such as Europeans and the indigenous population. Thus, until 1919 Arabs admitted to the Indies had their freedom of movement severely limited by a system of required residence in

23 Gobée and Adriaanse, Ambtelijke adviezen, 2: 1597.

24 The Arabic word for syekh is sheikh (plural: mashaikh). The word gabili means a member of a tribe. The Arabic plural is gabail.

25 Bujra, Politics of Stratification, passim.

${ }^{26}$ On this topic see Th. W. Juynboll, Handleiding tot de kennis van de mohammedaansche wet volgens de leer der sjafi'itische school (Leiden: Brill, 1930), pp. 186-87.

27 Gobée and Adriaanse, Ambtelijke adviezen, 2: 1579.

28 Bujra, Politics of Stratification, p. 79.

${ }^{29}$ Van der Meulen, Onbekend Arabië, p. 168. 
specified neighborhoods and travel passes. ${ }^{30}$ Before that year, they were only allowed to live in certain quarters of designated towns. These neighborhoods were administered by the colonial regime with the aid of Arab quarter heads who had the rank of lieutenant or captain, depending on the size of their community. At the beginning of this century, these kampung Arab were already overpopulated. If an Arab wished to leave his place of residence in order to trade or visit a family member, he was required to apply for a travel pass. Aside from curtailing their freedom of movement, other, separate legal rules also limited the economic freedom of Foreign Orientals. In the greater part of Java, for example, they were forbidden from owning land other than house allotments.

In spite of these hindrances, the Arabs succeeded in gaining an important position in the fields of both the economy and religion. In Batavia, Surabaya, and Semarang, as well as in smaller places like Cirebon, Gresik, Tegal, Pekalongan, Bangil, Bondowoso, and Sumenep, the Arab quarters grew into busy trade districts. ${ }^{31}$ Along with the Chinese, they controlled the intermediary trade, although each group concentrated on certain products. Among the Arabs these included clothing, construction materials, furniture, gems, perfumes, and religious literature. In several cities, they founded workshops where batik was printed and textiles were woven. Quite a number of Arabs functioned as money-lenders, with their reputations on the whole worse than those of their Chinese counterparts. The thriving usury cast a slur on the Arab community. If colonial administration reports are to be believed, in some areas the word Arab was synonymous with such terms as miser and swindler.32 Among the sayid there were many who acted as religious leaders and preachers, who in some regions had large followings among the local population. As descendants of the Prophet they were celebrated, and, just as in Hadramaut, graves of outstanding sayid became pilgrimage sites which were exploited by their descendants, whom Snouck Hurgronje once called "gravestone parasites." 33

Initially, the Arab community was a rather closed one. Although the immigrants married local women, these were forced to behave like women in Hadramaut. The number of marriages with indigenous women declined as more peranakan Arabs were born. Arranged marriages between Arabs who lived in widely separated places, even between Hadramaut and the Indies, were far from unusual and were arranged precisely to strengthen Arab community identity. Children were brought up as much as possible in the Hadrami way, and interaction between the sexes and between members of different social groups did not differ from those on the other side of the Indian Ocean. Internal social relationships reflected those in the homeland, at least until the second decade of this century.

\footnotetext{
${ }^{30}$ See Snouck Hurgronje on this in Gobée and Adriaanse, Ambtelijke adviezen, 2: 1580-82.

31 Only a few of these communities have been studied. On the Arab community in Surabaya see Abdul Rachman Patji, "Asimilasi golongan etnis Arab," in Masyarakat Indonesia 10, 1 (1983): 47-81; On the Arabs in Pekalongan see H. A. Thalib, "Masyarakat keturunan Arab di Pekalongan; studi tentang asimilasi" (thesis, Universitas Pajajaran, Bandung, 1976); C. Vuldy, "La communauté arabe de Pekalongan," Archipel 30 (1985): 95-119; C. Vuldy, Pekalongan, batik et islam dans une ville du nord de Java, Etudes insulindiennes-Archipel, no. 8 (Paris: Ecole des Hautes Etudes en Sciences Sociales, 1987).

32 See Oetarjo, "Over den woeker in de regentschappen Tegal, Brebes en Pemalang," Blaadje voor het volkscredietwezen 13, 8 (1925): 139-46; C. Heijer, "Rapport betreffende een onderzoek naar den woeker in Kediri en Zuid-Soerabaja," ibid., pp. 147-49.

33 Gobée and Adriaanse, Ambtelijke adviezen, 2: 1566.
} 


\section{Identification with the Arab World}

Until long after the turn of the century, the majority of Arabs in the Netherlands East Indies identified with their country of origin. This situation resulted in the first place from the continual stream of wulaiti, newcomers or totok Arabs, coming to the Indies, the close connections that existed between migrants and those who stayed behind, and the "temporary" nature of the migration. ${ }^{34}$ Other factors also strengthened Arab identity, however, such as the continual discrimination by the colonial authorities against Arabs, political developments in the Arabian peninsula, and pan-Islamism.

The status of Foreign Oriental was a thorn in the flesh of the Arab community. It not only impeded the further development of trade, but also injured their self-respect; they felt demoted to the status of second-class citizens. There were continual protests, especially by the sayid, against the settlement policies, the time-consuming process for issuing passes, and the inspection of papers on the road, which was felt to be degrading. Through appeals first to the Turkish government and later to the British, they attempted to change the mind of the colonial government and gain the status of Europeans. ${ }^{35}$

Snouck Hurgronje supported their objections to the limitations on travel. Time and again he complained in his recommendations to the governor-general about the "unpleasant" and "illegal" way the colonial authorities treated this section of the population. ${ }^{36}$ Civil authorities often seemed to exceed their authority in executing these regulations. The colony clearly did not lack "Araber-fresser." 37 Nonetheless, Snouck himself also recommended for a long time that the immigration of Arabs to the Dutch East Indies should be curtailed or ended. This friend of many prominent Arabs thought that the "mass of the people traveling this way grew up in surroundings where misery and poverty as well as delusion and fanaticism rule. They contribute little or nothing to the growth of trade and crafts, and their moral influence on the indigenous population is mostly harmful, although favorable exceptions can be noted." ${ }^{38}$ Snouck feared the political and religious influence of the Arabs: the spread of Islam and pan-Islamism.

For a long time the authorities ignored Snouck's advice. It is true that they were apprehensive of the ever-increasing stream of Arab immigrants, but for different reasons. Within the colonial administration more and more voices were raised to counter the pernicious influence of the Arabs on the economy. Lending money at extortionate rates of interest, renting houses for usurious fees, selling goods at unfavorable credit conditions, fictitious bankruptcies, and other dubious practices were thought to injure financially the local population. ${ }^{39}$ Although nothing showed that these kinds of practices were more prevalent

34 The terms wulaiti (Arabic) and totok Arab in Indonesian both refer to full-blooded Arabs.

35 Algemeen Rijksarchief, The Hague (henceforth ARA), Verbaal (Minute, henceforth Vb) 10-2-1921-X1, “De Arabische kwestie in Nederlandsch-Indië."

36 Gobée and Adriaanse, Ambtelijke adviezen, 2: 1566.

37 Ibid.

38 Ibid., p. 1533.

${ }^{39}$ For stereotyped examples of these practices see a.o. H. H. Dalman, "Woekerbestrijding door soepele credietverlening," Volkscredietzuezen 19, 1 (1931): 68-73; A. P. Noordink, "Over den woeker in de afdeeling Pekalongan," Blaadje voor het Volkscredietwezen 13, 9 (1925): 164-65; S. W. Sinambela, "Woeker in de desa," Volkscredietwezen 21, 8 (1933): 846-50. Dalman (p. 68) finds the Arab money-lenders more dangerous than the Chinese "because they are slyer and more cautious." Sinambela (p. 850) describes the way the Arab money-lenders go to work: "When he sees that a person has enough fields or a good house, he approaches him and asks if he has plans to borrow. He courts the prospective debtor, especially his children and he buys biscuits for them or gives them 10 to 30 cents. He talks about the religion, his and that of his potential borrower, and makes him believe that failing to 
among the Arabs than among other ethnic groups, an attempt was made in the second decade of this century to limit Arab immigration. Starting in 1915, people who were expected to have a deleterious influence on the economy were admitted only under certain conditions or were refused admittance to the country. This led to a storm of protest within the Arab community, and as early as 1919 the government was forced to withdraw the ruling. ${ }^{40}$

The policies of the Netherlands East Indies administration, however negative in themselves, had a great influence on maintaining Arab self-awareness. This consciousness was further strengthened by the international attention paid to their problems. Representatives of the Arab minority had brought the discriminatory treatment by the Dutch to the attention of the Turkish sultan as early as the end of the nineteenth century. They assumed a right to his intervention because he claimed nominal authority in the Hadramaut. Some Arabs even presumed that, on this basis, they had the right to Turkish nationality. Turkey was flattered, but could do little in view of its weak international position. However, it did use the Arabs' complaints for its own purposes: Turkey hoped to improve its involvement with the Arab world by expressing its concern about the situation. By making empty promises, the Turkish consuls in Batavia stirred up the disquiet in the Arab community. Anti-Dutch articles in the Turkish and Egyptian press also contributed to this restlessness. ${ }^{41}$

After the Hadramaut came under British influence, the Arabs turned to London. The British considered all Hadramis as "protected British subjects," and so migrants from this region were to experience no form of hindrance in the Straits Settlements. 42 Although the Dutch government did not share the British opinion about the nationality of the Hadramis, the British attitude contributed in large part to the discontinuance of the ban on Arab immigrants in 1919. In the same year the pass and quarter systems were terminated.43

More important to the sense of Arab unity among the Hadramis was Arab nationalism and the resurgent pan-Islamism of this period. The Turkish empire declined and finally fell apart in 1918. With aid or opposition from competing world powers, attempts were made to create new Arab and Islamic states everywhere in the Middle East. Arab nationalism received a tremendous response among the Arab minority in the Netherlands East Indies. This Arab awakening was closely connected with the modern pan-Islamism, that is to say with the idea that Islamic peoples had to unite in order to promote their interests. Some followers of Pan-Islam advocated a powerful political union of the Arab world. The fall in 1908 of the sultan of Turkey, who as caliph exercised temporal power over the Muslim world, led to all kinds of speculations about a new center for the caliphate. Most panIslamists saw the religious tie as a means of raising the consciousness and political independence of the Islamic peoples. The feeling of being a part of a unity that would champion the interests of its members supported the Hadramis in their quest for just treatment in the Dutch East Indies. ${ }^{44}$

make payments will not be considered a serious offence. If one considers the character of the natives in general, one knows that they cannot resist."

40 ARA, Vb. 10-2-1921-X1.

41 Gobée and Adriaanse, Ambtelijke adviezen, 2: 1717-52.

42 ARA, Vb. 10-2-1921-X1.

43 Ibid.

44 Gobee and Adriaanse, Ambtelijke adviezen, 2: 1709. 


\section{Discord between Sayid and Syekh}

Although pan-Islamism and Arab nationalism stirred up the Arab minority in the Dutch East Indies far into the 1930s, these were eclipsed by another development between 1912 and about 1934: the conflict between sayid and syekh. In 1901 Arabs founded in Batavia the Jamiyat Khair, the Association for the Good. This association was to maintain Arab culture and the Arab language by opening its own schools and by sending youths to Islamic countries for their continuing education. ${ }^{45}$ In 1912 three Arab teachers were recruited, one from the Sudan, one from Morocco, and one from the Hejaz. The Sudanese Ahmad Soerkati, who had long studied in Mecca, became an important religious leader. Within a few years he started a reformist movement that caused discord in the Arab community. ${ }^{46}$

From the beginning, Soerkati was offended by the traditional religious views and rigid social relations within the Hadrami immigrant community. He especially disagreed with the haughty way in which the aristocratic sayid behaved in Java. He was a follower of Muhammad Abduh and Rashid Rida, two modernist Egyptians who wanted to bring the Islamic experience into line with the demands of the time and who preached the equality of all believers. ${ }^{47}$ Soerkati's views soon led to heated discussions in the Arab community. ${ }^{48}$

The immediate cause of division within the community were his pronouncements about marriage and the kissing of the hand. During a visit to the head of the Arab community in Solo, he unequivocally let it be known that a marriage between a daughter of a sayid and a non-sayid is allowed, and is even in accordance with the kafa'ah. On another occasion he attacked the self-exaltation and delusion of sacredness of the sayid and argued for the abolition of the hand kiss. ${ }^{49}$ Both events had a tremendous impact among the Arabs. The sayid were deeply insulted and felt themselves threatened. The non-sayid who agreed with Soerkati seized on the pronouncements in order to extricate themselves from sayid influence. Soerkati was forced to leave the Jamiyat Khair, and in 1914 he founded the Jamiyat al-Islah wal-Irsyad, the Association for Reform and Leadership, abbreviated to Al-Irsyad. ${ }^{50}$ This association became the bastion of the anti-sayid or the syekh, which became the general term for all non-sayid. Its history embodies, to a large extent, the emancipation of the lower classes in the Arab community.

The Irsyad, which, like the Jamiyat Khair, soon had local branches and schools throughout the country, aimed to purify Islam of superstitions and additions. Besides, it wanted to denigrate the Hadrami class structure. It was not descent but the equality of people (sama rasa sama rata) that was central for the Irsyadi. Through modern education, moreover, they wanted to promote Arab self-expression and social mobility in Java and elsewhere in the colony. ${ }^{51}$

\footnotetext{
45 See pamphlet Menjelang 60 tahun berdirinya Yayasan Perguruan Al-Irsyad Surabaya (Surabaya: Yayasan Perguruan "Al-Irsyad," 1981), p.18.

${ }^{46}$ Cf. Deliar Noer, The Modernist Muslim Movement in Indonesia, 1900-1942 (Kuala Lumpur: Oxford University Press, 1973), pp. 58-63; G. F. Pijper, Studiën over de geschiedenis van de islam in Indonesië, 1900-1950 (Leiden: Brill, 1977), p. 110.

47 ARA, Mailrapport (henceforth MR) 1042 geheim (secret) 1929, letter of April 4, 1928.

48 ARA, MR 685 geheim 1931 and MR 792 geheim 1931.

49 B.J. Schrieke, "De strijd onder de Arabieren in pers en literatuur," Notulen van de algemeene en directievergaderingen van het Bataviaasch genootschap van kunsten en wetenschappen 58 (1921): 190-91.

${ }^{50}$ Pijper, Geschiedenis van de islam, pp. 109, 113.

51 Cf. Yayasan Perguruan Al-Irsyad; Schrieke, "Strijd onder de Arabieren."
} 
This difference of opinion led to a long period of animosity between the two parties. Years of relative quiet alternated with years of open enmity in which sayid and syekh opposed each other in word and deed. In local Arab papers, pamphlets, brochures, and edifying texts, positions were defended and attacked. ${ }^{52}$ Sometimes the polemics grew into real abuse. The sayid accused the syekh among other things of communism, slander, and heresy, while Soerkati was called a "negro" and "a seed of discord." 53 The syekh in turn reproached the sayid for their "pride, haughtiness and notoriously sinful behavior." some places the differences of opinion were fought out by newly formed local associations, which walked in step with either the Irsyad or with the recently founded Rabitah al'Alawijah, the union of descendants of the Prophet. Now and then riots broke out. Opponents were denied admittance to the mosque, were pelted with stones, or fought out their differences in the street. In Pekalongan a school building was set on fire. ${ }^{55}$

However, not everyone was happy with these periodic eruptions, which fouled the Arabs' own nest and in some sense isolated them from the rest of society. Between 1915 and 1930 several attempts were made to bring about a reconciliation between the parties, each time without success. An attempt in 1928 by the highly respected, very rich Hadrami al-Qaf from Singapore failed, while the good offices of al-Amoedi, an Arab from Ambon, in 1929 also came to naught. ${ }^{56} \mathrm{Al}$-Amoedi attempted to start a dialogue by bringing friendly and opposing associations together in a federation, the Wahdah al'Arabijah (Arab Unity). He also started a special association for Arabs born in the Dutch East Indies, the IndonesianArab Union. The mistrust between the participating associations was so great, however, that after a short period both organizations became dormant. 57

\section{The Title Fight}

Tensions reached a high point in May 1931 when, during an Irsyad congress in Batavia, the decision was made no longer to consider the title sayid as a prerogative of the Ba-'Alawi. Sayid was not a noble title, the congress decided, but just meant "mister," "sir," "tuan," or "monsieur." It was recognized that in some Arab regions it was also used to refer to a respectable or generous person or as term of address or synonym for husband, master, leader, or prince, but, at the same time, it was emphasized that it was never reserved for a certain group. Therefore, each Arab had the right to add the predicate to his name, as was usual in a number of Arab countries. The decision struck at the raison d'être of the sayid. It meant that they could no longer differentiate themselves from the rest of the population as descendants of the Prophet, and that they would lose the privileges attached to that position. In short, they feared the end of their aristocratic privileges. ${ }^{58}$

After the congress, the whole Arab community was in great uproar. The syekh provoked the Alawi by registering members of their group who married as sayid, adding the term to

\footnotetext{
52 For details see Schrieke, "Strijd onder Arabieren." He deals in particular with the articles which appeared in Al-Iqbal, but constantly refers to other newspapers and periodicals.

53 Schrieke, "Strijd onder Arabieren," pp. 193. 199, 209.

54 Ibid., p. 217.

55 Gerakan Al-Irsjad; Koempoelan toelisan-toelisan jang berhoeboeng dengan gerakan dan congres Al-Irsjad serta beberapa poetoesannja (Batavia: Secretariaat Vereniging "Al-Irsjad", 1934), p. 98.

56 ARA, MR 1064 geheim 1929 and MR 233 geheim 1939.

57 Ch. O. van der Plas, " De Arabische gemeente ontwaakt," Koloniaal Tijdschrift 20 (1931): 178.

58 ARA, MR 1265 geheim 1932, letter June 20, 1931.
} 
the nameplates on their houses, and introducing themselves to outsiders as sayid. ${ }^{99}$ On June 10, several weeks after the congress, the Rabitah al 'Alawijah petitioned the governorgeneral for legal protection of the title of sayid. ${ }^{60}$ In support of the request, the association pointed to the separate regulations in such areas as marriage and inheritance law that were in force for the descendants of the Prophet among the Syafi'i school, which is followed by nearly all Muslims in Indonesia. It also emphasized that for several centuries the Arab minority in the Netherlands East Indies had been divided into sayid and non-sayid and that this differentiation had always been officially recognized in passports, contracts, and notarial acts. In contrast with the Irsyadi, the Alawi were, moreover, of the opinion that in the Muslim world the title sayid was generally reserved for the descendants of Husein. Based on historical, juridical, and linguistic grounds, the association thought that only the Alawi had rights to the title. ${ }^{61}$ It feared that when every Hadrami could call himself sayid, "undesirable events" would occur in the areas of religion and commerce, not to speak of what would happen to "social life in the Dutch East Indies in general."

During the following months detailed expositions on the meaning of the term sayid appeared in Hadramauth, the conservative organ of the Alawi, and in Ad-Dahna, the progressive paper of the syekh. ${ }^{62}$ Also for the first time the non-Arab press began to interest itself in the "title fight." The Malay Chinese papers Keng Po, Siang Po, and Sin Tit Po let sayid and syekh carry on a discussion in their columns. ${ }^{63}$ The parties juggled with words. Hair splitting, delusions, and red herrings blurred the real concern of the argument: the emancipation of the non-Alawi.64

In order to curb the animosity that was palpable in every Arab quarter, discussions were held at the end of the year between representatives of the Alawi and the Irsyadi. At the conclusion "peace terms" were signed and a supervisory committee was formed. The negotiators called for a "spirit of brotherhood and equality of rights" with regard to religious and social relationships, but at the same time announced that they had not reached an agreement about religious differences. For this reason they requested that mutual opinions be respected, as long as these were not in conflict with the four mazhab, the four Islamic schools. The parties agreed that the "sad past of discord and dissension" had to be buried. Referring to Allah's words "the faithful are brothers," they were asked to stop despising each other in word and deed. The article dealing with this said:

One should not ridicule another, nor give another insulting names, nor insult [each] other's ancestry while both parties must forbid the uneducated among themselves from doing such things (...). During meetings and in schools moreover everything that is not in accordance with Islamic law or gives offense and can cause discord must be avoided for the Words of God: "Do not slander each other and do not give each other insulting nick names." ${ }^{\prime 65}$

\footnotetext{
${ }^{59}$ On the alleged misuse of the title sayid see ARA, MR 1265 geheim 1932, a.o. letters February 12, 15, 19, 1932, September 9, 10, 1932.

60 ARA, MR 1265 geheim 1932, letter June 20, 1931.

61 In this connection the authors also refer to Snouck Hurgronje's Mekka, vol. 1 (The Hague: Nijhoff, 1888), p. 56ff, and De Atjèhers, vol. 1 (Batavia/Leiden: Landsdrukkerij/Brill, 1893), pp. 158, 160.

62 ARA, MR 1265 geheim 1932, "Overzicht van de Arabische pers."

63 See Gerakan.

64 The most important articles from Keng Po, Siang Po, and Tit Sin Po are collected in Gerakan.

65 ARA, MR 1265 geheim 1932, Appendix A.
} 
How divided the community was, appears also from the call to reinstate traditional customs, such as greeting each other, making sick calls, and participating in funeral processions without discrimination.

The sayid viewed the peace accords as a defeat and did not accept them. They felt that Soerkati, who represented the Irsyadi, had outwitted Agil Badjerei, the negotiator of the Alawi. In November 1931 a letter from the Rabitah al 'Alawijah was once again sent to the government, this time to point out that article 507 of the Criminal Code stated that the unlawful use of a Dutch or indigenous title was punishable. They thought that the title sayid and sayidah (only sporadically was the female title mentioned) should also fall under this formulation. The association also pointed to article 156 of the same law code which said that it was against the law to express "feelings of animosity, hate, or contempt" against one or more population groups in the Netherlands East Indies, where group signified "each part of the population (...) that differentiates itself from one or more parts of that population by race, ethnicity, religion, origin, descent, nationality or constitutional position." 66 The Alawi thought they had found a new argument for protecting their title and position in the legal criteria of descent.

In the first half of 1932, serious riots took place once again in the Arab quarters. In some cities they resulted in bloodshed. ${ }^{67}$ In the mosque of the Arab community in Bondowoso (East Java), several Irsyadi who pushed forward during a service were shot down by sayid.68

Meanwhile the top leadership of the Al-Irsyad wrote the governor-general registering their objection to the Ba-'Alawi's petition and requesting that the government not take sides in the conflict. 69 They contested the superior position of the sayid, pointing out in this regard that a comparable difference of opinion had occurred in the first centuries after the rise of Islam. This dispute had resulted in the separation of the Shi'ites who wanted to maintain the privileged position of the descendants of the Prophet. According to the writers of the letter, the privileges of the sayid have always been disputed among the Sunnis. They viewed the high position of the sayid particularly in the Hadramaut as resulting from the fact that, until its conquest by Ibn Saud, Mecca had been ruled by syarif, descendants of Husein's brother Hasan. The sayid's claims to high status were said to have been strengthened in the Netherlands East Indies because the local population venerated the sayid as saints and because the government regularly consulted "prominent and indisputably able members of that group in political matters."70

Halfway throught the year, the Rabitah again approached the government which had still taken no action. The Rabitah pointed to the existence under the earlier caliphs of a separate department to control the purity of the sayid and syarif lines and to promote their interests. In those days the appropriation of the title had been punishable. Under the Turkish caliphs, all kinds of decrees confirmed the distinguished position of the Hadrami sayid. There existed, on paper in each case, a separate forum privilegatum for this group. Aside from

66 Ibid., Appendix B, letter November 24, 1931.

67 Indisch Verslag 1932, Vol. 1, "Tekst van het verslag van bestuur en staat van Nederlandsch-Indië over het jaar 1932," (The Hague: Algemeene Landsdrukkerij, 1933), p. 15.

68 In 1987 I spent some time in this place and found that the incident still divides the local Arab community into two camps.

${ }^{69}$ ARA, MR geheim 1932, letter February 12, 1932.

70 Ibid. 
these arguments, they cited Arab works that confirmed the aristocratic position of the sayid. ${ }^{71}$

Although the conflict was ignored by the majority of the population of the Netherlands East Indies and was insignificant in comparison with other problems that occurred in those years, it nevertheless contained national and international dimensions. The social and religious ideas of the Al-Irsyad did not differ much from those of the Muhammadiyah, the most important indigenous Islamic reform movement. According to Pijper, Soerkati's work was an important source of inspiration for this organization in its early years. ${ }^{72}$ It is, therefore, not surprising that the Muhammadiyah supported the goals of the progressive Arabs, as did the Partai Sarekat Islam Indonesia. Both Tjokroaminoto and Haji Agus Salim, together the most important leaders of this party, more than once voiced pro-Irsyad opinions. The sayid were supported in particular by the Nahdatul Ulama, a party in which traditionally oriented rural kiai, religious leaders, played an important role. Like the sayid, the religious leaders felt themselves threatened by the desire for religious renewal and social change.

The internal divisions in the Arab community in the Netherlands East Indies had also not escaped attention from the inhabitants of Hadramaut and Hadrami colonies in other countries: the conflict led to sharp altercations between the traditional classes there. ${ }^{73}$ For this reason, the English initially (until 1920) refused to give passports to Irsyadi who wanted to travel to the Hadramaut or the Straits Settlements. ${ }^{74}$ Both the sayid and syekh sought the support of like-minded Hadrami abroad. The sayid knew, in any case, that the al-Qua'ity sultan was on their side. In a letter to the government, the sultan had called those who used the sayid title illegally criminals and propagandists for socialism and bolshevism. ${ }^{75}$ The syekh were assured of the support of the modernist movements in the Middle East. Their ideas were repeatedly defended in the international Arab press. ${ }^{76}$

The title fight not only undermined the social cohesion of the Arab community; it also had severe consequences in the economic field. Employees from opposing sides were dismissed and debts to adversaries were no longer paid off. Arab business declined and traders lost part of their clientele. Some entrepreneurs invested so much money in the conflict that they teetered on the edge of bankruptcy. According to Hadramauth, the official journal of the Alawi, the Arabs were "financially and morally so weakened that their future was threatened."77 The dissension also did not improve the negative image that outsiders had for many years of Arab businessmen.78

In February 1933 the government answered the petitions from both parties. ${ }^{79}$ It had decided not to intervene, but left the sayid free to put 'al-'Alawi' after their names in official documents, in distinction to the syekh. In this the government followed the advice of its department for Indigenous Affairs, but deviated from the position of its most important

\footnotetext{
71 ARA, MR 1265 geheim 1932, letter May 9, 1932.

72 Ibid., letter June 20, 1932.

73 Bujra, "Political Conflict"; Kostiner, "Hadrami Emigrants."

74 About this case see ARA, Vb. 10-2-1921-X1.

75 ARA, MR 1265 geheim 1932, "Overzicht van de Arabische pers."

76 Jbid.

7 Hadramauth August 11, 1932.

78 ARA, MR 511 geheim 1934, Appendix.

79 ARA, MR 141 geheim 1933, letter February 3, 1933.
} 
adviser Snouck Hurgronje, who agreed with the sayid's demands. ${ }^{80} \mathrm{He}$, in fact, proposed changing the criminal code in such a way that "current Arab titles in the East Indies" became legally recognized.

The sayid were disappointed. The proposal to add the words 'al-'Alawi' to their name was indignantly rejected. The government's decision not to intervene implied that henceforth each Arab in the Dutch East Indies could use the title sayid. What was meant as a neutral stand, resulted in a serious loss of face for the descendants of Muhammad. By submitting new letters endorsing their view, including one from the senate of the al-Azhar University in Cairo ("the greatest and most important body of scholars in the Islamic world"), the sayid still tried to turn the tide. Violent reactions, such as those in the preceding period, however, did not occur. The sayid began to realize that social relations within the Arab community and within the world at large had irreversibly changed. During the years of commotion new boundaries had gradually come into being, such as between the totok Arabs and the peranakan Arabs, between progressive and conservative sayid, and between the youth and the elders. It was the young peranakan Arabs who were able in the late 1930s to push the internal division further into the background.

\section{Integration in the Wider Society}

Early in 1934 a congress was organized in Pekalongan by the sayid allied to the Rabitah al 'Alawijah in order to discuss the government's negative decision regarding the title question and to prepare new protests. During the congress, however, the younger participants were able to outvote their vindictive elders, who for the most part had been born in the Hadramaut, and these younger men succeeded in removing the question about the title from the agenda. According to them, this was not a favorable time to renew action. Moreover, they openly asked if it were worth the trouble to return to this subject. Through wellprepared and tactical actions they were able to advance more important subjects, such as the modernization of education and the fight against the hated usurious practices of the Arabs. ${ }^{81}$

Another more unsettling event took place in Semarang at the end of 1934. On October 4, thirty-nine young progressive sayid and syekh who had been born in the Netherlands East Indies declared that they no longer viewed Hadramaut as their motherland, but rather Indonesia, as the Indies were increasingly being called in nationalistic circles. These young progressives took a vow that, as children of the country, they would fight for the territory and society of Indonesia. The next day they founded the Persatoean Arab Indonesia (PAI), the Union of Indonesian Arabs. The union explicitly opposed the divisions in the Arab community and sought to increase the cooperation and solidarity among Indonesian Arabs. At the same time they wanted to liberate them from Hadrami social relations and integrate them into Indonesian society. For this reason they decided, among other things, to abolish the use of the title sayid within their own circle and to use Malay as their common language. 82

${ }^{80}$ Snouck Hurgronje later retreated from this position, although the reasons for his change of opinion can no longer be ascertained because the documents containing his advice have been lost. He then joined the government's position. See Gobée and Adriaanse, Ambtelijke adviezen, 2: 1598-99.

81 ARA, MR 511 geheim 1934, letter April 7, 1934.

82 See ARA, MR 463 geheim 1937, letter May 7, 1937; Abud Sanad et al., Hari kesadaran bangsa Indonesia turunan Arab (Surakarta: Panitia Peringatan, 1956); Hamid Algadri, C. Snouck Hurgonje, Politik Belanda terhadap Islam dan keturunan Arab (Jakarta: Sinar Harapan, 1984), pp. 161-63; A. R. Baswedan, Sumpah pemuda Indonesia keturunan Arab (1934) (Surabaya: Pers Nasional, 1974). 
The founder and leader of the PAI (which existed until the Japanese invasion) was the well-known journalist A.R. Baswedan. At an early age Baswedan, who was born on Java in 1908, strove hard for the emancipation of the Arab community and its integration into the wider Indonesian society. He propagated his ideas in pro-nationalistic newspapers such as Sin Tit Po, Soeara Oemoem, and Matahari. ${ }^{83} \mathrm{He}$ fought against the prevailing notion among Arabs that Indonesia was only a temporary domicile and criticized the rancor among totok Arabs against deviant views. In Matahari he once compared the situation of the Arabs in the archipelago with a bobbing boat that is out of control, being tossed now westwards, now eastwards. ${ }^{84}$

If feelings in the Arab community had calmed somewhat after the title question, the formation of the PAI caused a new stir. The union's goals were criticized from all sides. Especially the acknowledgement of Indonesia as motherland created resentment within the Arab community. According to Pijper,

many Arabs, even within the association itself, could not identify themselves with the thought that one would have to exchange the Arab homeland for an Indonesian motherland; remaining Arabs, it is true, but still giving up much of what earlier generations had considered the highest national inheritance. ${ }^{85}$

After a slow and disputed start, the PAI gained ever more followers, in particular among the peranakan Arabs who made up about two thirds of the Arab community. At the time of its fourth congress in 1939, PAI had twenty-eight branches in the Netherlands East Indies. Baswedan regarded this as slow growth and compared it to the "sleeping child" of a Persian queen that had been born only after a pregnancy of five years. According to him, the PAI's ideal needed an even longer period of growth in the minds of the Arabs. ${ }^{86}$

Until 1936 the PAI pursued mainly social, religious, and cultural goals. It published two periodicals, Sadar ("Conscious") and Insjaf ("Realization") to inform the Arab community about its ideals and pursuits. ${ }^{87}$ It zealously advocated the expansion of educational facilities in Arab circles and pleaded in this connection for the foundation of three more Dutch-Arab schools, in addition to the existing one in Solo, where children could prepare themselves for further studies. ${ }^{88}$ Just like other nationalist-oriented sister organizations, it founded a youth section and a women's association. The effort to emancipate women of Arab descent may be seen as especially revolutionary in Arab circles at that time. ${ }^{89}$ The PAI also called on Arabs to end existing usurious practices which, although committed by only a few, made the whole community look bad. By cooperating economically with Indonesians, it hoped moreover to stem the continual flight of capital to Hadramaut. ${ }^{90}$

83 S. Maskatie, "Ar. Baswedan didalam dan diloear pergerakan," in Ar. Baswedan: Boeah fikiran dan andjoerannja, ed. S. Maskatie (Surabaya, 1939), pp. 6-14.

${ }^{84}$ Ar. Baswedan, "Sekeliling soal tanah air," in Baswedan: Boeah fikiran, p. 23.

85 ARA, MR 463 geheim 1937, letter May 7, 1937.

86 ARA, MR 463 geheim 1937, "Verslag Arabisch congres te Soerabaia"; ARA MR 582 geheim 1939.

87 Abud Sanad et al., Hari kesadaran, p.4.

88 In 1930 a private Arab school with a Western curriculum had been taken over by the government and changed into a Dutch-Arab school. See Van der Plas, "De Arabische gemeente," p. 182.

89 See Barkah Nahdi, "Sekitar P.A.I. isteri," in Congresnummer P.A.I, 1934-1941, ed. Comité Congres (Surakarta, 1941), pp. 33-34.

90 ARA, MR 463 geheim 1937, "Verslag Arabisch congres te Soerabaia." 
As the PAI gained in importance, it also became politically more active. From 1936 on it openly joined the ranks of the nationalists. In 1936 it supported the famous petition by Soetardjo, an Indonesian member of the Volksraad, in which a careful plea was made for a free and independent Indonesia within the context of a Dutch-Indonesian union. In 1937 it asked the government to admit more Arab members to the Volksraad, without thereby reducing the number of representatives of other foreign Asian minorities. In addition it exerted itself for equal rights for peranakan and totok Arabs, arguing that members of the second group should also be able to become Dutch Indies subjects. In 1939 the association joined the Madjlis Islam A'laa Indonesia, the federation of Indonesian Islamic political associationsevidence that it had been recognized by nationalistic sister organizations. In 1939 and 1940 the PAI supported the actions for a full-fledged democratically chosen Indonesian parliament taken by the Gaboengan Politik Indonesia (GAPI), the alliance of Indonesian political parties. ${ }^{91}$ The association's increased political orientation is also evident from the change of name it adopted in 1940: from then on the initials PAI stood for Partai Arab Indonesia.92

The extent of the difference in the attitude of the Arab members of the PAI toward their new motherland is shown in a verse from the association's song:

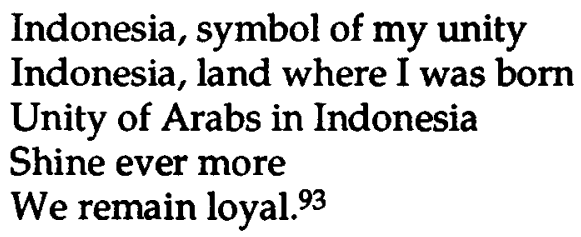

In reaction to the PAI, the earlier Indonesian Arab association of al-Almoedi (see page 82) took on a new lease on life under the name of the Indo-Arab movement. The movement tried to channel the dissension among those Arabs who disagreed with the PAI, and, in order to guarantee Arab interests, it took a pro-Dutch position. It opposed the PAI's nationalistic ideals and fought for the maintenance of Arab consciousness. ${ }^{94}$ It wanted to be part of Indies society but simultaneously wished to maintain close, non-political ties to the people of Hadramaut. To put an end to the desolate economic situation, in which peranakan Arabs in particular found themselves after the years of discord, its leaders argued for the founding of special trade organizations. ${ }^{95}$ The movement gained a following in conservative sayid circles, but never had much influence, as the political tide was against it. Political developments in Asia at the end of the 1930s favored the nationalistic movements.

In a period of less than ten years, the Arab community moved from a preoccupation with problems mostly relating to social identity and feelings of being discriminated against by the sayid, to confronting basic questions of national identity: whether or not to choose Indonesia as their motherland.

\footnotetext{
91 On the political course of the PAI see Hamid Algadri, C. Snouck Hurgronje, pp. 165-72; A. R. Baswedan, "Apa sebab2nya gerakan bangsa Indonesia turunan Arab berhasil?," in Hari Kesadaran, pp. 5-8; A. R. Baswedan, "P.A.I. dan Front-democratie," in Congresnummer P.A.I, pp. 23-24; J. Pluvier, Overzicht van de ontwikkeling van de nationalistische beweging in de jaren 1930 tot 1942 (The Hague/Bandung: Van Hoeve, 1953), pp. 90-91.

92 Hamid Algadri, C.Snouck Hurgronje, p. 165.

93 ARA, MR 1115 geheim 1938, letter November 21, 1938.

94 Pluvier, Nationalistische beweging, p. 91.

95 ARA, MR 233 geheim 1939, letter February 17, 1939.
} 


\section{Conclusion}

In the years between the turn of the century and the Japanese invasion in 1942, the Arabs in the Netherlands Indies experienced important changes in social and national identification. The rigid, hierarchical social order from Hadramaut was to a large degree overthrown, the relatively isolated Arab community became more open to developments in the wider Indonesian society, and a growing number of Arabs realized that Indonesia rather than Southern Arabia had become their motherland.

Until the beginning of the twentieth century, for the most part, Arab immigrants identified with the Hadramaut. To be sure, they had settled in the Indonesian archipelago, whether temporarily or permanently, but in principle they had only economic and familial ties to their new environment. Both as Arabs and as Muslims their primary involvement was with developments in their own land, their land of origin, and with the Arab world at large. Interest in developments in the local Indonesian society were limited to the economic nexus. Like so many other immigrants of both Asian and European origin, they saw their new environment primarily as a place to make money. This orientation was strengthened by the Dutch colonial policy. Its policies on immigration, the regulations on travel and residence, and the separate laws for Foreign Orientals made the Arabs perceive the colonial government as hostile to them. This perception led them to become to a certain degree fiercely anti-Dutch. This stance only lessened after the discriminating decrees on migration and settlement were canceled in 1919.

After the turn of the century, more and more Arabs began to express their discontent with the strict maintenance of the Hadrami social structure in their new environment. To an increasing extent the traditional societal ranking seemed to them an anachronism. Within a relatively short time this development divided the immigrant community into two camps: the conservative sayid who wanted to hold on to the old social order from Hadramaut and the progressive syekh who strove for a democratic society.

The discord manifested itself most clearly in the title fight which took place between 1912 and 1934, and which was not only a symbol of the existing social tensions within the Arab community, but also formed the crux. The winner of the fight was at the same time the winner of the social struggle. Although the colonial government considered the confrontation officially undecided, the syekh emerged the moral winners. Both in a metaphorical sense (i.e. the title fight) and in reality, they had freed themselves from the smothering influence of the sayid. It meant the end of the traditional social order and the coming into being of new identities.

The title fight not only resulted in changes in social identity among the Arabs in the Netherlands Indies but also had severe consequences for Arab feelings of national identification. In fact, their social and national identities were closely connected, although not perceived as such. Until the beginning of the 1930s, problems within the Arab community dominated all other issues. Above all the Irsyad was an emancipation movement opposed to the discrimination of the syekh by the sayid. For the Arab minority it was an anathema for a long time to view Indonesia as their home land. They hardly spoke or wrote about the issue, and only after the unexpected public oath taken by Baswedan and his companions in October 1934 did it become a topic of discussion. Until now that date is remembered as the day on which the Arabs became aware of their Indonesian identity (Hari Kesadaran Bangsa Indonesia Keturunan Arab).

The syekh, in particular, who had emancipated themselves in a social sense, increasingly realized that, as far as their feelings of nationality were concerned, they were closer to 
Indonesia than to Southern Arabia. To a considerable degree they had already detached themselves from events in the Hadramaut, and, without giving up their Arab consciousness, they increasingly identified with their country of residence. But even among the sayid more and more voices were heard urging the recognition of Indonesia as their motherland. The young peranakan, in particular, who, like the young syekh, felt alienated from their land of origin, became conscious that one could no longer live between two motherlands. The majority of the older totok sayid, however, continued to identify with the Hadramaut, not least because of the loss of their privileged position.

At the end of the 1930s, the greater part of the Arab community had not only come to identify with Indonesia as its motherland, but also to sympathize with the nationalist goals. This consciousness and concern were in particular the result of the activities of the PAI, which closely cooperated with pro-nationalist organizations. In a figurative sense, the PAI demolished the barriers which still stood between the Arabs and the outside Indonesian world. It brought the Arabs into closer contact with all kinds of autochthonous and allochthonous groups and made them conscious of their own position.

In a timespan of forty years, the Hadrami minority in the Netherlands Indies developed from a predominantly Arab-oriented community with an Indonesian imprint into a predominantly Indonesian-oriented group with an Arab signature. 